\title{
Total Synthesis of (-)-Chokol A by an Asymmetric Domino Michael Addition- Dieckmann Cyclization ${ }^{1}$
}

\author{
Ulrich Groth, * Christian Kesenheimer, Paul Kreye \\ Fachbereich Chemie, Universität Konstanz, Universitätsstraße 10, Postfach M-720, 78457 Konstanz, Germany \\ Fax +49(7531)884155; E-mail: ulrich.groth@uni-konstanz.de
}

\begin{abstract}
A convergent and asymmetric total synthesis of (-)chokol A was accomplished in six steps starting from the $\alpha, \beta$-unsaturated ester $(E)-9$ in an overall yield of $27 \%$ with an enantiomeric excess of $95 \%$. The key step of this synthesis is the asymmetric tandem conjugate addition-Dieckmann cyclization of the higherorder cuprate $\mathbf{8}$ derived from vinyl bromide $\mathbf{7}$ with the $\alpha, \beta$-unsaturated ester $(E)-9$.
\end{abstract}

Key words: antifungal agents, asymmetric synthesis, Michael addition, tandem reaction, total synthesis

(-)-Chokol A (1) is a fungitoxic, modified sesquiterpene ${ }^{2}$ isolated from the stromata of timothy grass Phleum pretense infected by the pathogenic fungus Epichloë typhina. This antimycotic natural product was isolated for the first time in 1985 by Yoshihara et al. ${ }^{3}(-)$-Chokol A (1) and the more active chokols B (2), C (3), D (4), and G (5, Figure 1) have received special attention due to their fungitoxic properties. 4

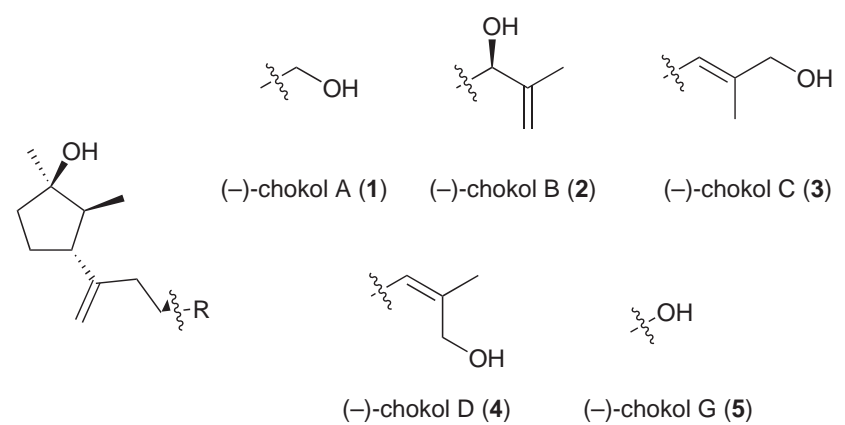

Figure 1 Representative members of the chokole family

Since the discovery of $\mathbf{1}$, so far five racemic ${ }^{5}$ and only four enantioselective $^{6}$ syntheses have been described for chokol A. In 1987 Mash $^{6 a}$ presented the first asymmetric synthesis of (-)-chokol A (1). Key step of this synthesis was the diastereoselective cyclopropanation of a chiral ketal. The overall yield was $9 \%$ over 13 steps with an enantiomeric excess of approximately $80 \%$. The last synthesis of (-)-chokol A (1) was described by Helmchen et al. ${ }^{6 \mathrm{~d}}$ in 1995 . They converted the well-established 2-oxocyclopentenecarboxylate in six steps into the natural product (-)-1 with an overall yield of $22 \%$ and $\geq 99 \%$ ee.
In 2004 we have reported the enantioselective synthesis of 2,3-disubstituted cyclopentanone derivatives via a combination of an asymmetric Michael addition and a Dieckmann cyclization. ${ }^{7}$ This type of reaction belongs to the domino processes. ${ }^{8}$

Based on these results, an enantioselective synthesis of (-)-chokol A (1) was explored.

Starting the convergent synthesis with the benzylation of 2-bromo-5-hydroxypentene $(6)^{5 \mathrm{~d}, 9}$ (Scheme 1) following a protocol given by Gewald et al. ${ }^{10}$ we obtained the bromo-vinyl building block 7 , which is essential for the synthesis of the higher-order cuprate $\mathbf{8}$. Compound $\mathbf{7}$ was then treated with 2 equivalents of tert-butyllithium, followed by 0.5 equivalents of copper(I) cyanide and 0.5 equivalent of borontrifluoride in order to afford the cuprate $\mathbf{8}$.
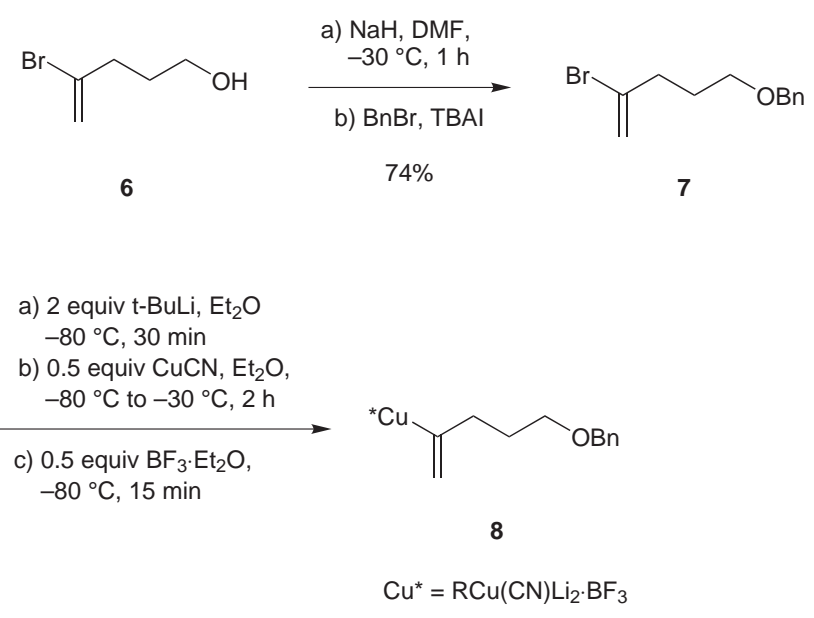

Scheme 1 Synthesis of the higher-order cuprate 8

The $\alpha, \beta$-unsaturated ester 9 (Scheme 2) was synthesized according to a formerly published route ${ }^{7}$ by addition of (-)-phenylmenthol to 2-chloro-acetylchloride followed by a Michaelis-Arbuzov reaction with triethyl phosphite. The resulting diethoxy phosphonic ester was then converted into the $\alpha, \beta$-unsaturated ester 9 via a WittigHorner reaction with methyl-4-oxo-butanoate. By employing this reaction sequence, we have generated the chiral Michael acceptor 9 in three steps with a yield of $83 \%$ over the whole sequence.

Addition of the cuprate $\mathbf{8}$ to the chiral ester $\mathbf{9}$ (Scheme 2) in diethyl ether at $-115^{\circ} \mathrm{C}$ gave after a Michael addition followed by a Dieckmann cyclization the cyclic $\beta$-keto 


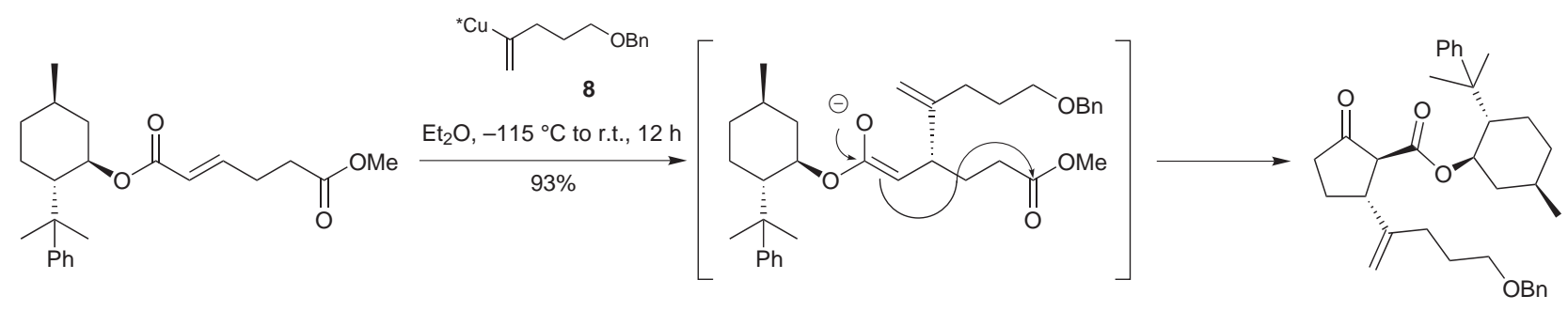

9

$10 a$

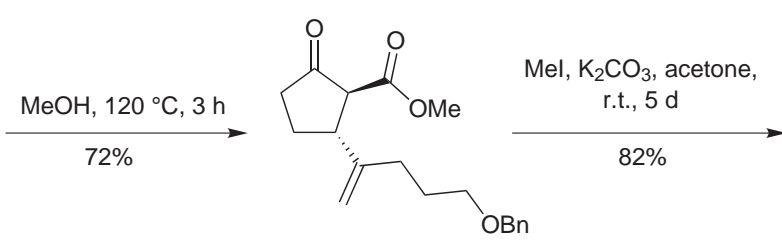

11
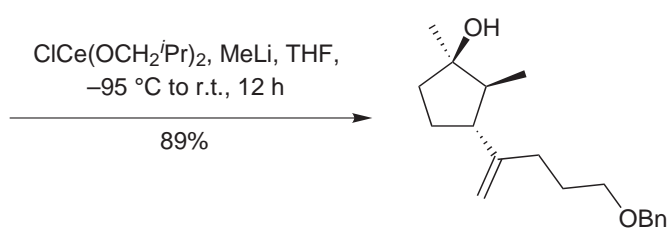

15

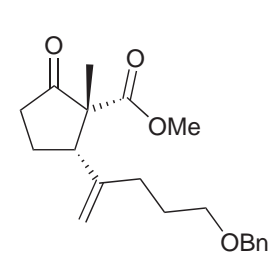

13

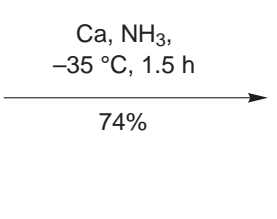

as a necessity for the feasibility of this reaction. ${ }^{12 b}$ In order to synthesize the tertiary alcohol at the $\mathrm{C} 1$ position we used cerium(III) reagents as nucleophiles, which were generated in situ from methyllithium and chlorocerium(III)dialkoxides. Best results were obtained by employing chlorocerium(III)di-neopentoxide for this reaction. Addition of this cerium(III) reagent afforded compound $\mathbf{1 5}$ after aqueous work-up in $89 \%$ yield with a diastereomeric excess of $88 \%$ (Table 1).

Table 1 Addition of Different Cerium(III) Reagents to 14

\begin{tabular}{lll}
\hline Reagent & Yield of $\mathbf{1 4}(\%)$ & de $(\%)$ \\
\hline $\mathrm{MeCeCl}_{2}$ & 91 & 63 \\
$\mathrm{MeCe}(\mathrm{O} i-\mathrm{Pr})_{2}$ & 83 & 79 \\
$\mathrm{MeCe}(\mathrm{O} t-\mathrm{Bu})_{2}$ & 85 & 82 \\
$\mathrm{MeCe}\left(\mathrm{OCH}{ }_{2} i-\mathrm{Pr}\right)_{2}$ & 89 & 88 \\
\hline
\end{tabular}

Because of their high steric demand and the oxophilic nature of cerium, the cerium(III) reagents are specially suited for addition reactions to carbonyl groups that easily undergo enolization. ${ }^{13}$ The cleavage of the benzyl ether under mild conditions was then achieved by the use of calcium in liquid ammonia. The use of calcium in ammonia proved to be mild enough to cleave the benzyl ether without affecting the double bond. So finally, after column tion succeeded even without an $\alpha$-proton between the $\mathrm{C}$ keto function and the ester, although this was postulated 


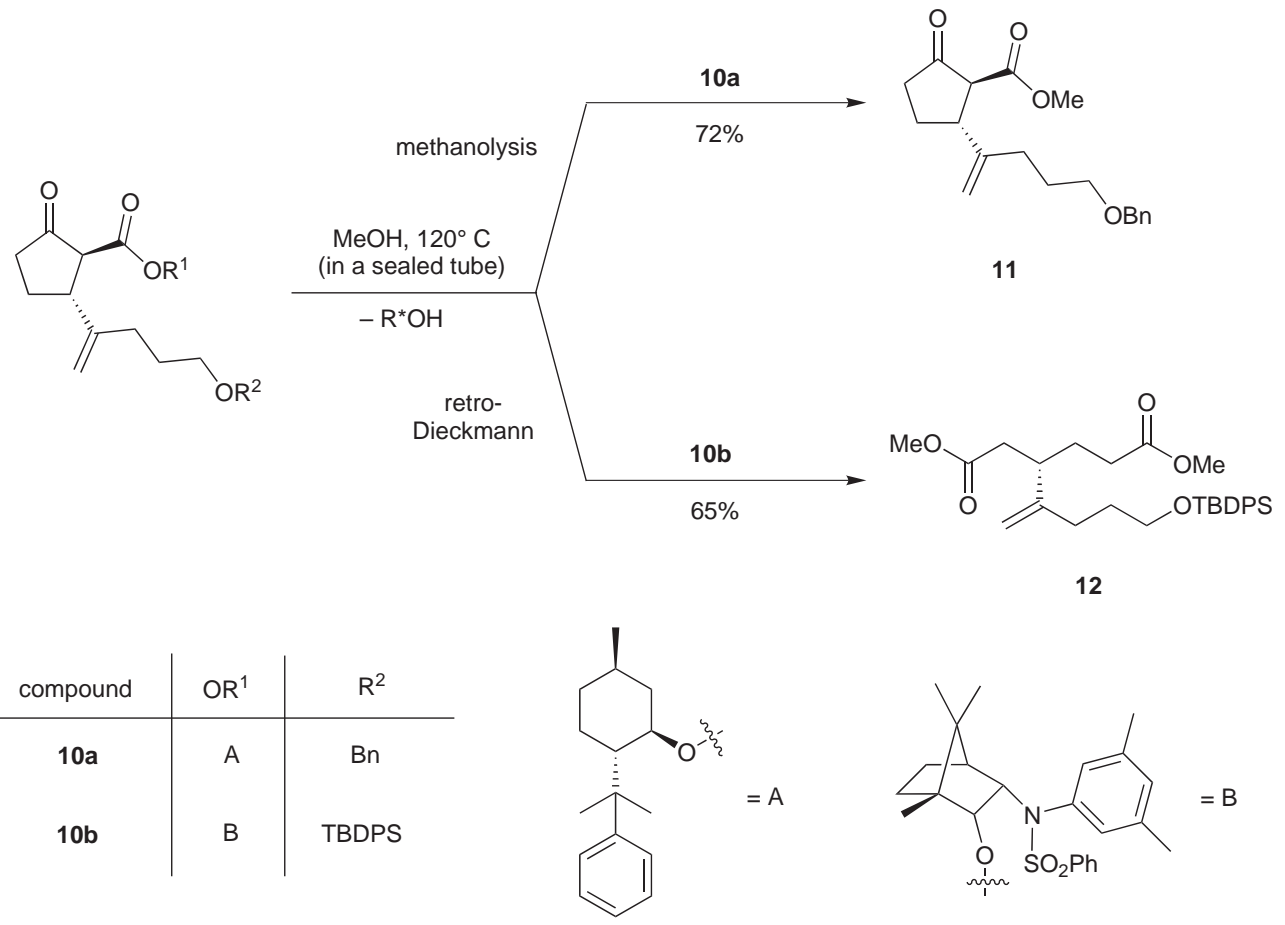

Scheme 3

chromatography we isolated the natural product (-)chokol $\mathrm{A}$ in $74 \%$ yield and the enantiomeric excess was determined to be $\geq 95 \%$ by comparing its optical rotation $\left\{[\alpha]_{\mathrm{D}}{ }^{20}-56.2(c 0.58, \mathrm{EtOH})\right\}$ with the data reported earlier. $^{6}$

\section{Acknowledgment}

The authors are grateful to Metallgesellschaft AG and Wacker AG for providing valuable starting materials. P.K. thanks the CusanusWerk - Bischöfliche Hochbegabtenförderung - for a doctoral fellowship.

\section{References and Notes}

(1) (a) Stereoselective Synthesis of Steroids and Related Compounds, IX. For part VIII, see: Groth, U.; Kalogerakis, A.; Richter, N. Synlett 2006, 905. (b) Lanthanides in Organic Synthesis, part VI. For part V, see: Groth, U.; Kesenheimer, C.; Neidhöfer, J. Synlett 2006, 12, 1859.

(2) Koshino, H.; Yoshihara, T.; Togiya, S.; Terada, S.; Tsukada, S.; Okuno, M.; Noguchi, A.; Sakamura, S.; Ichihara, A. Tennen Yuki Kagobutsu Toronkai Koen Yoshishu 1989, 31, 244.

(3) Yoshihara, T.; Togiya, S.; Koshino, H.; Sakamura, S.; Shimanuki, T.; Sato, T.; Tajimi, A. Tetrahedron Lett. 1985, 26, 5551.

(4) Sakamura, S. In Biologically Active Natural Products Potential Use in Agriculture; Culter, H. G., Ed.; ACS Symposium Series, Vol. 380, Oxford University Press: New York, 1988.
(5) (a) Oppolzer, W.; Cunningham, A. F. Tetrahedron Lett. 1986, 27, 5467. (b) Lawler, D. M.; Simpkins, N. S. Tetrahedron Lett. 1988, 29, 1207. (c) Tanimori, S.; Ueda, T.; Nakayama, M. Biosci. Biotechnol. Biochem. 1994, 58, 1174. (d) Groth, U.; Halfbrodt, W.; Köhler, T.; Kreye, P. Liebigs Ann. Chem. 1994, 9, 885. (e) Deloux, L.; Srebnik, M. Tetrahedron Lett. 1996, 37, 2735.

(6) (a) Mash, E. A. J. Org. Chem. 1987, 52, 4142. (b) Suzuki, T.; Sato, E.; Matsuda, Y.; Tada, H.; Koizumi, S.; Unno, K.; Kametami, T. J. Chem. Soc., Chem. Commun. 1988, 1531. (c) Suzuki, T.; Tada, H.; Unno, K. J. Chem. Soc., Perkins Trans. 1 1992, 2017. (d) Urban, E.; Knühl, G.; Helmchen, G. Tetrahedron 1995, 51, 13031. (e) For the enantioselective synthesis of (-)-chokol G, see: Kanada, R. M.; Tanaguchi, T.; Ogasawara, K. Chem. Commun. 1998, 1755.

(7) Groth, U.; Halfbrodt, W.; Kalogerakis, A.; Köhler, T.; Kreye, P. Synlett 2004, 291.

(8) For recent reviews on domino reactions, see: (a) Tietze, L. F. J. Heterocycl. Chem. 1990, 27, 47. (b) Tietze, L. F.; Beifuss, U. Angew. Chem., Int. Ed. Engl. 1993, 32, 131; Angew. Chem. 1993, 105, 137. (c) Tietze, L. F.; Bachmann, J.; Wichmann, J.; Burkhardt, O. Synthesis 1994, 1185. (d) Tietze, L. F. Chem. Ind. (London, U.K.) 1995, 453. (e) Tietze, L. F. Chem. Rev. 1996, 96, 115. (f) Tietze, L. F.; Modi, A. Med. Res. Rev. 2000, 20, 304. (g) Tietze, L. F.; Haunert, F. Domino Reactions in Organic Synthesis. An Approach to Efficiency, Elegance, Ecological Benefit, Economic Advantage and Preservation of our Resources in Chemical Transformations, In Stimulating Concepts in Chemistry; Shibasaki, M.; Stoddart, J. F.; Vögtle, F., Eds.; Wiley-VCH: Weinheim, 2000, 39-64. (h) Tietze, L. F.; Rackelmann, N. Pure Appl. Chem. 2004, 76, 1967.

(i) Tietze, L. F.; Brasche, G.; Gericke, K. Domino Reactions in Organic Synthesis; Wiley-VCH: Weinheim, 2006.

(9) For the synthesis of 2-bromo-5-hydroxypent-2-ene 7, see also: Lawler, D. M.; Simpkins, N. S. Tetrahedron Lett. 1988, 29,1207 
(10) Gewald, K.; Jänsch, H. J. J. Prakt. Chem. 1973, 4, 779.

(11) $\left(1 S, 2 S, 1^{\prime} R, 2^{\prime} S, 5^{\prime} R\right)$-2-[1-(3-Benzyloxypropyl)vinyl]-5oxocyclopentanecarboxylic Acid [5'-Methyl-2'-(1methyl-1-phenylethyl)]cyclohexyl Ester (10a)

To a solution of $2.55 \mathrm{~g}$ (10.0 mmol) 2-bromopentenylbenzyl ether (7) in $20 \mathrm{~mL}$ of abs. $\mathrm{Et}_{2} \mathrm{O} 10.0 \mathrm{~mL}(20.0 \mathrm{mmol}, 2 \mathrm{M}$ solution in $\mathrm{Et}_{2} \mathrm{O}$ ) of $t$ - $\mathrm{BuLi}$ was slowly added at $-90{ }^{\circ} \mathrm{C}$ and stirred then at this temperature for $90 \mathrm{~min}$. The resulting organolithium compound was then added at $-80^{\circ} \mathrm{C}$ via canula to a suspension of $0.45 \mathrm{~g}$ (5.0 mmol) copper(I) cyanide in $10 \mathrm{~mL} \mathrm{Et}_{2} \mathrm{O}$ and stirred then for $2 \mathrm{~h}$ until the temperature reached $-30{ }^{\circ} \mathrm{C}$ and the suspension turned into a bright-green solution. After cooling the solution again to $-80{ }^{\circ} \mathrm{C} 0.64 \mathrm{~mL}(5.0 \mathrm{mmol}) \mathrm{BF}_{3} \cdot \mathrm{OEt}_{2}$ were added by syringe and stirred for $15 \mathrm{~min}$, whereupon the solution was cooled to $-115^{\circ} \mathrm{C}$ by an EtOH-dry ice bath. After reaching this temperature a degassed solution of $0.37 \mathrm{~g}(1.0 \mathrm{mmol})$ of the chiral ester 9 in $10 \mathrm{~mL} \mathrm{Et}_{2} \mathrm{O}$ was added (very) slowly to the solution of the higher order cuprate $\mathbf{8}$ and the resulting reaction solution was then stirred for $12 \mathrm{~h}$ under warming to r.t. For the work-up $30 \mathrm{~mL}$ of a sat. $\mathrm{NH}_{4} \mathrm{Cl}$ solution were added to the black suspension, stirred for 2-3 min and then filtered over Celite ${ }^{\circledR}$. After phase separation the aqueous phase was extracted 3 times with $25 \mathrm{~mL}$ portions of $\mathrm{Et}_{2} \mathrm{O}$. The combined organic phases were dried over $\mathrm{MgSO}_{4}$ and concentrated with a rotary evaporator at $30{ }^{\circ} \mathrm{C} / 13 \mathrm{mbar}$. The resulting residue was then purified via column chromatography over $200 \mathrm{~g}$ silica gel with $\mathrm{PE}-\mathrm{Et}_{2} \mathrm{O}=2: 1$ as eluent, which gave $0.48 \mathrm{~g}$ ( $0.93 \mathrm{mmol}, 93 \%$ yield $)$ of the compound 10a (Figure 2). The diastereomeric excess was determined to be $>95 \%$ by ${ }^{13} \mathrm{C}$ NMR spectroscopy. $R_{f}=0.35$ $\left(\mathrm{PE}-\mathrm{Et}_{2} \mathrm{O}=2: 1\right) .{ }^{1} \mathrm{H} \mathrm{NMR}\left(200 \mathrm{MHz}, \mathrm{CDCl}_{3}\right): \delta=0.85$ $\left(\mathrm{d}, 3 \mathrm{H},-\mathrm{CH}_{3}, J=6.3 \mathrm{~Hz}\right), 1.18\left(\mathrm{~s}, 3 \mathrm{H},-\mathrm{CH}_{3}\right), 1.26(\mathrm{~s}, 3 \mathrm{H}$, $\left.-\mathrm{CH}_{3}\right), 1.34-2.39\left(\mathrm{~m}, 18 \mathrm{H}, \mathrm{H} 2-\mathrm{H} 4, \mathrm{H}^{\prime}-\mathrm{H}^{\prime}\right.$ and $\mathrm{H} 2^{\prime \prime}-$ H3"), 2.86-2.88 (m, $1 \mathrm{H}, \mathrm{H} 1$ ), 3.5 (t, $2 \mathrm{H}, \mathrm{H} 4^{\prime \prime}, J=6.2 \mathrm{~Hz}$ ), 4.52 (s, $\left.2 \mathrm{H},-\mathrm{CH}_{2} \mathrm{Ph}\right), 4.76-4.83\left(\mathrm{~m}, 2 \mathrm{H}, \mathrm{C}=\mathrm{CH}_{2}\right), 7.06-$ $7.50(\mathrm{~m}, 10 \mathrm{H}, 2 \times \mathrm{Ph}) .{ }^{13} \mathrm{C} \mathrm{NMR}\left(50.3 \mathrm{MHz}, \mathrm{CDCl}_{3}\right)$ : $\delta=21.71\left(\mathrm{C5}^{\prime}-\mathrm{CH}_{3}\right), 26.29\left[\mathrm{C}^{\prime}-\mathrm{C}\left(\mathrm{CH}_{3}\right)_{2} \mathrm{Ph}\right], 26.56\left(\mathrm{C}^{\prime}\right)$,

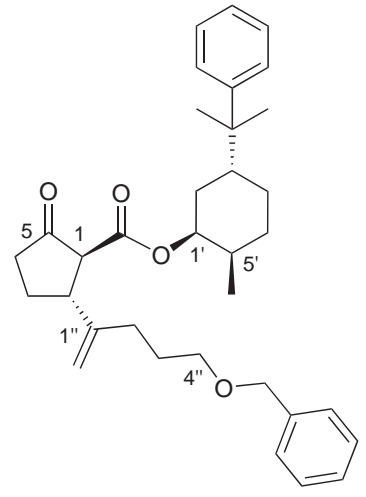

Figure 2

$26.83\left[\mathrm{C}^{\prime}-\mathrm{C}\left(\mathrm{CH}_{3}\right)_{2} \mathrm{Ph}\right.$ ], $26.90\left(\mathrm{C3}^{\prime \prime}\right), 27.96\left(\mathrm{C5}^{\prime}\right), 30.96$ (C3), 31.25 (C2'), 34.48 (C4'), 38.09 (C4), 39.81 [C2'$\left.\mathrm{C}\left(\mathrm{CH}_{3}\right)_{2} \mathrm{Ph}\right], 41.22(\mathrm{C} 2), 45.13\left(\mathrm{C}^{\prime}\right), 49.90\left(\mathrm{C}^{\prime}\right), 60.35$ (C1), $69.66\left(\mathrm{C}^{\prime \prime}\right), 72.91\left(\mathrm{OCH}_{2} \mathrm{Ph}\right), 76.27\left(\mathrm{Cl}^{\prime}\right), 109.38$ $\left(\mathrm{Cl}^{\prime \prime}=\mathrm{CH}_{2}\right), 124.90\left(\mathrm{C}_{\text {para.Ph }}\right), 125.42\left(\mathrm{C}_{\text {ortho,Ph }}\right), 127.48$ $\left(\mathrm{C}_{\text {para,Bn }}\right), 127.55\left(\mathrm{C}_{\text {ortho,Bn }}\right), 127.92\left(\mathrm{C}_{\text {meta,Ph }}\right), 128.30$ $\left(\mathrm{C}_{\text {meta.Bn }}\right), 138.42\left(\mathrm{Cl}_{\mathrm{Bn}}\right), 148.38\left(\mathrm{Cl}^{\prime \prime}\right), 151.21\left(\mathrm{C}_{\mathrm{Ph}}\right)$, $167.49\left(-\mathrm{CO}_{2} \mathrm{R}\right), 210.23(\mathrm{C} 5)$. MS (EI, 70eV): $\mathrm{m} / \mathrm{z}(\%)=$ $516.4(0.1)\left[\mathrm{M}^{+}\right], 302.2(52.0)\left[\mathrm{M}^{+}-\mathrm{C}_{16} \mathrm{H}_{22}\right], 119.1(50.0)$ [Ph-C $\left.\left(\mathrm{CH}_{3}\right)_{2}{ }^{+}\right], 91.1(100.0)\left[\mathrm{C}_{7} \mathrm{H}_{7}{ }^{+}\right]$. IR (film): 3020, 3005 $\left(\mathrm{C}=\mathrm{CH}_{2}\right), 1745(\mathrm{C}=\mathrm{O}), 1710\left(-\mathrm{CO}_{2} \mathrm{R}\right), 1640(\mathrm{C}=\mathrm{C}) \mathrm{cm}^{-1}$. $[\mathrm{a}]_{\mathrm{D}}{ }^{20}+4.21\left(c 1.13, \mathrm{CHCl}_{3}\right)$. Anal. Calcd for $\mathrm{C}_{34} \mathrm{H}_{44} \mathrm{O}_{4}: \mathrm{C}$, 79.03; H, 8.58. Found: C, 78.90; H, 8.71.

(12) (a) Parish, E. J.; Mody, N. V.; Hedin, P. A.; Miles, D. H. J. Org. Chem. 1974, 39, 1592. (b) Huang, B.-S.; Parish, E. J.; Miles, D. H. J. Org. Chem. 1974, 39, 2647. (c) For a review article about this topic, see: Krapcho, A. P. Synthesis 1982, 805.

(13) Alcarez, C.; Groth, U. Angew. Chem., Int. Ed. Engl. 1997, 36,2480 . 